\title{
The Impact of Policy Changes at the Pre-University Education on Teaching, Learning, and Student Performance
}

\author{
Ramlee Ismail*, Khoo Yin Yin \\ Faculty of Management and Economics, Universiti Pendidikan Sultan Idris, Malaysia
}

Received October 9, 2019; Revised November 22, 2019; Accepted December 26, 2019

Copyright $\odot 2020$ by authors, all rights reserved. Authors agree that this article remains permanently open access under the terms of the Creative Commons Attribution License 4.0 International License

\begin{abstract}
Purpose of the study: This study aims to investigate the impact of pre-university education reforms on students' performance, teaching and learning process, school management and demand and supply of Economics course at pre-university level. Methodology: A quantitative research approach involves data collection using survey design and interviewing of Economics teachers from high schools in the state of Perak and Kelantan. Data were analysed using descriptive analysis and pair sample t-test. Data also collected using interview for triangulation and analysed manually. Main Findings: The findings of this study showed that pre-university reforms had given a positive impact on teaching preparation, teaching and learning implementation, school management, reducing teacher's workload and enhancing students' performance. However, pre-university educational reforms are not significantly impacting the demand for the economics subject at this level. Applications of this study: This research is useful to provide information, input and knowledge for those who want to choose between Form Six education, matriculation or diploma as their path to higher education institutions. Novelty/Originality of this study: This paper investigates an early impact of the pre-university policy reform, in particular to the classroom environment for teaching, learning and management for the economic subject. The source of information for data gathering comes from teachers who experienced before and after the reforms.
\end{abstract}

Keywords Pre-University, High School Economic, Policy And Reform, School Management

\section{Introduction}

The adoption of global economics, technology and industrial changes by the school and educational systems are needed. It is essential to ensure that education in this country will provide to the next generation who are ready and willing to accept global changes. Therefore, a curriculum should be sensitive by using fluid and organic curriculum that can change when the market improves. Overall, a significant curriculum change was referred to an introduction of the integrated curriculum in 1989 and its revision, in 2003. In 2017, the integrated curriculum changed to a new 'standard curriculum' which takes into account the challenges of the $21 \mathrm{st}$ century, the new economic model and current teaching and learning methods. Economic subjects in high schools are also revised to ensure that students can gain fundamental knowledge and economic terms, to relate concepts and economic principles to reality, to analyse and evaluate information clearly and accurately. However, economics content in high school or pre-university has not changed significantly, except for the mode of delivery, namely modular system. A modular system refers to pre-university education, which is using a semester-based system. Before 2012, pre-university schooling system takes two years for completion. Currently, it will take one and a half year to complete in the modular system was introduced with a minor change in the economics curriculum. The main purpose is to improve teaching and learning orientation in Form Six (F6) or pre-university education so that there is not much difference in the teaching and learning orientation in colleges or universities. A new curriculum for the economics subject is involved in updating titles, content, and skills to keep pace with the current economic changes and developments, including a topic on a small and medium-sized industry. Besides, the syllabus also emphasises on improving writing skills, findings and analysing information, solving problems, and communicating effectively with students through research 
and coursework. In short, changes in the pre-university education system from two years to the three semester's system have affected the syllabus and assessment. It also influences the teaching preparation and demand and supply for an economic subject at pre-university as well. However, to what extent these changes can affect teaching and learning, or preparation and administration of this subject can only be seen through a comprehensive study. Therefore, as a preliminary, this study also examines the immediate impact in the context of the subject's demand and supply, the preparation and planning of the teacher, the teaching and learning process and the achievement of the students compared to the past. The objective of this study is to identify the impact of pre-university educational structural changes to the teaching preparation, planning, teaching and learning process, assessment (assessment) for the economic subject. This study also examines the impact of the system reform on demand and supply, student's achievement in Economic subjects before and after the change.

\section{Literature Review}

The Ministry of Education of Malaysia (2008) has rebranded the pre-university education to be more characterised by the university system by including lectures and tutorials. Form Six (F6) or pre-university education reforms initiative also comes with the transformation of the administration system. It is one of the strategies to upgrade Form Six to be in line with its status as a pre-university education that serves to equip students who will study in the environment of tertiary institutions. A change in the education system for Form Six (pre-university) involves three elements. First, the duration of the study, which is a new system, consists of three semesters or one and a half year as compared to the previous period (two years). The changes in the study system began by introducing the modular concept that replaced the Terminal System. The Terminal system refers to the previous Form Six schooling system, which is comprised of Lower Six and Upper Six and the Modular (current system) with three semesters. Secondly, the student's assessment involved two components, which comprise the final exam at the end of a semester and coursework through a semester in the Modular System.

In contrast, an assessment in the Terminal system is carried out at the end of the second year of the study period. Lastly, pre-university or Form Six education management in the modular system which is branded by three mods, namely Mod One (1) or F6's college that the school has at least 12 classes. Mod Two (2) is a school that has 12 Form Six classrooms but located in the same compound with other classes but a separate building. The school is managed by the principal and assisted by Senior Assistants. The schools with F6 less than 12 classrooms and school management is under the same Principal is a Mod Three category.

The general requirements for Form Six or Pre-university enrolment must be a graduate of upper secondary education, the ages of between 17 and 20 years at the year of application, and possess the Malaysian Certificate of Education (MCE) examination with at least credits in the Malay Language and other requirements (depends on what type of secondary education they have completed). For the Science stream, students need to possess at least three credits with a total grade score of not more than 18 units for three subjects from different groups in their MCE. Admission from secondary school or technical secondary school requires at least three credits with total grade points not exceeding 12 units for three subjects from various groups. Students from the religious high schools (such as Religious Secondary School, the Government Aids Religious School and Federal Religious Schools) require at least a Grade D for Arabic subjects and earn at least three credits with a total grade score of not more than 14 units. For full religious boarding schools, the entry requirement is to get at least a Grade $\mathrm{C}$ in the Arabic language and at least three credits with total grade points not exceeding 14 units (MoE, 2015).

The objectives of pre-university education are to improve the education standard in a higher direction. Second, to provide a high level of the competitive education system. Third, to provide an education, which is equivalent to other levels of pre-university programmes. Fourth, to ensure that the students who have completed Form Six schooling receive a recognised by the labour market. Finally, to instil the leadership attitude towards the development of unity, patriotism, and identity to support national aspirations. Pre-university education is also an educational route for students to develop their talents and creativity to become a high-impact, global and universal young generation (Ministry of Education, 2012). Form Six education in Malaysia comprises two main components, which are curriculum and co-curriculum (MoE, 2012). Both aspects included in the merit score of admission in order to apply for a place in the universities. The outcome of teaching and learning in pre-university education are cognitive skills, manipulative skills and soft skills. These skills were assessed based on the national examination. However, an assessment method for co-curricular activities arises, which is a concern regarding validity and reliability.

The Ministry of Education Malaysia (2012) reported that the number of candidates who's at for the Malaysian Certificate of Education (MCE) in 2009 is eligible to continue their studies into Form Six in 2010 were 201,200 students in total. However, only 27.7 per cent enrolled in the F6 (55,845 students), while 145,454 students ( 73.3 per cent) took a different path of tertiary education. Out of the total number of students enrolled in Lower Six, 48,245 completed (86.39 per cent) the Sixth Form in 2011 while a 
total of 7,600 students (13.61 per cent) dropped out after registering. The difference between the students pursuing the Sixth Form and the students who refused to complete in Form Six were 104,809 students. This figure shows that most students are less interested in continuing their studies in the Sixth Form. They accepted various offers from the public and private higher education providers to pursue their studies.

The transformation in the structure of pre-university studies involves a change in the Economic subject contents where the new components included research elements. The implementation of this element is indirectly promoting active learning methods, which exist in the literature (Carlson \& Skaggs, 2000; Ginsburg, 2009; Jensen \& Owen, 2003; Maier \& Keenan, 1994; Manning \& Riordan, 2000) of student's understanding. This method is useful in the teaching and learning of economic subjects (Becker, 1997; Becker \& Watts, 2001; Hansen, 2001; Khoo Yin Yin, 2008; Salami, 2002). Cross (1987), MOE (2005), Siegfried et al. (1991) and Whiting (2006) concluded that the involvement of students is needed to achieve the learning outcomes. Teacher-centred learning activities give students less opportunity to apply and develop cognitive and affective skills. As a result, students will receive passive information from the teacher and then re-apply what the teacher has to say. This phenomenon is contrary to the aims of the learning process to increase student participation actively in learning (Niemi, 1997; Simon, 1997; Slavin, 1997). Implementing coursework will involve group discussions, problem-solving, simulations, games and case studies, thereby, giving students the opportunity to voice and support their ideas as well as to hear the views and opinions of others (Meyers \& Jones, 1993). With this in mind, students can exchange ideas and interact freely with their classmates. Furthermore, the activities of the study will attract students and make the learning environment more fun, lively and cheerful (Salemi, 2002) as it enhances students' understanding and their academic achievement (Carlson \& Velenchik, 2006; Bartlett, 2006; Buckles \& Siegfried, 2006; Carlson \& Velenchik, 2006).

The findings of previous studies conducted by researchers show that involvement in learning activities can increase students' interest in Economic subjects (Brokaw \& Merz, 2004; Dixit, 2006; Strow \& Strow, 2006). However, curriculum changes that emphasise on the enhancement of active learning and dependency on teachers do not necessarily have a positive impact on achievements and outcomes in the labour market. For example, Berkhout et al. (2011) found that the pre-university curriculum changes in the Netherlands did not affect the achievement of students in college as well as in institutions of higher learning. However, in Japan, it's different as any changes in the curriculum are for pre-university to address the problems of teachers' inability to efficiently teach the subject concepts and content (Yamaoka et al., 2010). Therefore, it is significant to research and can be considered as one of the earliest efforts to examine the impact of the Sixth Form Education structure change. The T6 school system is a vital academic route as it is the last pit stop for students to pursue university-level studies. Any changes taking place should be evaluated or reviewed as they involve the teaching and facilitating the process of teachers, assessment and ultimately, the opportunity for students to pursue their academic agenda. This study only considers the experience of teachers as the primary source that will respond to the information needed. Processes or effects on students are also based on teachers' experience as they are in the educational system before and after the change.

\section{Research Methodology}

This study is to identify the impact that the reorganisation and re-branding of Form Six have on teachers' planning and preparation for teaching and learning activities. This study uses quantitative methods in which data are collected using questionnaires, while the secondary data are from the government and ministry reports and interviews with teachers. The design of the study constitutes the form of instrument preparation, which is the questionnaire, conducting a pilot test to determine the percentage of reliability of the instrument, collecting data and analysing. The questionnaire used in this study assesses the process of planning, preparing and teaching the teachers for economic subjects. The survey used was based on items developed by researchers and colleagues that divided into five (5) sections. Part A consists of information regarding the respondents' demographics containing twelve (12) questions, including the achievement of the Economic subject for four years before and after the change. Part B consists of thirty-eight (38) items relating to teaching and learning, which are the planning and preparation of teachers, student preparation, implementation and evaluation. Part $\mathrm{C}$ and $\mathrm{D}$ are associated with the committee and subject management as well as the teacher's workload. The total number of questions amounted to ten (10) each. The last part of the questionnaire was on the demand and supply for eleven (11) items. For further information, data also collected through an interview for triangulation purposes. Structured questions will be used involving five to 10 teachers from selected schools.

A pilot study was conducted, which involved 30 teachers from one of the states in Peninsular Malaysia, namely Pahang. In this study, the actual sample of the survey includes 500 respondents; which is quite significant if 70 to 89 respondents, between 14 and 18 per cent of the actual sample, were taken for the pilot test (Mahdzan, 2005). The sample size in the pilot study itself can be analysed because it satisfies the 'large sample' 
requirement in statistical knowledge $(\mathrm{n}>30)$. This pilot study to ensure the suitability of the language and that the items constructed to match with the issues or research questions. Furthermore, it will also identify the level of validity of the instrument. Besides, the pilot studies can also assist researchers in ensuring that our items are not deviated from what is to be achieved in this study. A total of 64 items was constructed to measure the structural changes over the seven elements of teaching and learning for the economic subject at the high school level. Table 4.2 shows the Alpha Cronbach values ranging from 0.75 to 0.85 . None of the items was dropped from the original item constructed, where the Alpha value for all items was 0.907 .

Table 1. Item Reliability [done]

\begin{tabular}{clcc}
\hline No & No of Item & $\begin{array}{c}\text { Alpha Cronbach } \\
\text { (Item) }\end{array}$ \\
\hline 1 & $\begin{array}{l}\text { Planning and } \\
\text { preparation }\end{array}$ & 14 & .757 \\
\hline 2 & Student preparation & 7 & .788 \\
\hline 3 & Implementation & 7 & .781 \\
\hline 4 & Assessment & 6 & .780 \\
\hline 5 & Subject management & 9 & .853 \\
\hline 6 & Workload & 10 & .762 \\
\hline 7 & Demand and supply & 10 & .762 \\
\hline & Total & 64 & .907 \\
\hline
\end{tabular}

The permission to conduct this study was obtained from the Ministry of Education Malaysia. Further arrangement from the state, district education and schools' office were also required. Subsequently, after the pilot study, the questionnaires were distributed to all economics teachers from the states of Kelantan and Perak. A total of 57 government-aided schools in Perak and 53 schools in Kelantan are selected as a sample. Perak and Kelantan were chosen as samples because both states are the traditional market for Form Six education, and some schools showed good performance in the last three years. The total number of teachers in these two states is about 110 teachers who will answer the questionnaires, and ten teachers were invited as a sample for interviews and focus group discussions. Out of a total of 110 questionnaires sent to schools in Kelantan and Perak, which offer high school economic (HSE), only 50 per cent returned to the researchers.

In summary, most schools, which are offering HSE, use mode two and three, i.e. secondary schools with separate administration were $41.4 \%$ while those with joint administration was 56.9 or 33 schools. However, only one (1) school was under the college's mode. Most of the teachers involved in the teaching and learning at HSE level are experienced teachers, of which $75 \%$ of them have more than ten years of experience in schools.

With regard to gender, female teachers are more than $70 \%$. In respect of qualification, only $12 \%$ of the Form
Six teachers possessed a Master's degree, and the rest obtained a bachelor degree. In terms of teaching licensing, $49 \%$ got a teaching qualification with their first degree in education. The other half received their teaching licence by post certificate in teacher training (9\%); diploma in education $(30 \%)$; and post-diploma in education $(12 \%)$. Most of the teacher'sspecialisation in economics at university level $(81 \%)$ while the rest is from related areas such as business or accounting.

A guideline was developed to examine the impact of this change (positive or negative), where the impact refers to the teachers' views and their experiences before and after the change. The measurement of impact is by using a simple indicator calculated by - (Likert scale -1$) / 2$ ) for the range. The interval of impact is as follows: $1+1.5=2.5$, therefore the range of $0-2.5$ becomes a negative impact if the mean value is smaller than 2.5; and a positive impact when the mean value is between 2.56 to 4.00 . For the purpose of comparison, we deploy a pair sample t-test to investigate a school performance before dan after policy changes. Therefore, the data for school performance, which is measured by the mean score of economic subject (national examination) for each school within four years before and after the education reforms was collected.

\section{Analysis and Discussion}

The impact of structural changes for pre-university education involved six elements, namely teaching planning, including student preparation, implementation of teaching and learning process, assessment, school management and teacher's workload.

\subsection{Student Preparation}

Table 2 shows the eight factors that were used to measure students' preparation in their study. Students' learning preparations in modular systems according to the views of their teachers overall showed a positive impact. Students are more focused and creative in their learning. However, students need guidance in conducting their coursework, adjusting and critical thinking in their F6E studies.

Table 2. Student Preparation

\begin{tabular}{lll}
\hline & \multicolumn{1}{c}{ Student Preparation } & Mean (SD) \\
\hline 1 & Easy to cope & $2.72(0.56)$ \\
\hline 2 & Attitude and mentally more prepared & $2.64(0.58)$ \\
\hline 3 & More focus & $3.00(0.47)$ \\
\hline 4 & Curriculum is specific & $3.00(0.48)$ \\
\hline 5 & Student oriented & $2.98(0.48)$ \\
\hline 6 & More creative & $3.17(0.46)$ \\
\hline 7 & Coursework is well prepared & $2.80(0.65)$ \\
\hline
\end{tabular}




\subsection{Implementation of Teaching and Learning (T\&L)}

In general, more than 80 per cent of the teachers argued that these changes make it easier for them to implement T\&L. It is easier to plan and uses more optimum time because of the separation of the subject scope in the modular system. Learning activities are more accessible to implement, and teachers act as facilitators. Teachers' planning and preparation in the modular system had a better effect than the previous system. Almost all the items on preparation and planning for teaching and learning in the current system much better compared to the previous system. However, our survey shows that assistance from state coaches was limited.

Table 3. Teaching and Learning Process

\begin{tabular}{lll}
\hline & \multicolumn{1}{c}{ Implementation } & Mean (SD) \\
\hline 1. & $\begin{array}{l}\text { Teaching implementation is easier than } \\
\text { before }\end{array}$ & $3.07(0.46)$ \\
\hline 2. & Teaching and learning is structured & $3.09(0.39)$ \\
\hline 3. & Teaching and learning is punctual & $3.12(0.47)$ \\
\hline 4. & $\begin{array}{l}\text { Teaching activities are easier to } \\
\text { implement }\end{array}$ & $3.12(0.47)$ \\
\hline 5. & The teacher is a facilitator & $3.19(0.58)$ \\
\hline 6. & Student learning oriented & $3.04(0.50)$ \\
\hline 7. & Efficient time management & $3.02(0.61)$ \\
\hline
\end{tabular}

\subsection{Assessment}

The Form Six subject assessment in the modular system shows that the evaluation processes are more robust compared to the terminal system. Learning outcomes are more comfortable to measure and, most importantly, students benefit greatly from the coursework in an economic subject as compared to the previous delivery system. Coursework also helps or contributes to a better grade for the students.

Table 4. Assesment

\begin{tabular}{lll}
\hline \multicolumn{1}{c}{ Assessment } & Mean (SD) \\
\hline 33. & Easy to conduct enhancements activities & $3.02(0.61)$ \\
\hline 34. & Classroom monitoring & $3.07(0.46)$ \\
\hline 35. & $\begin{array}{l}\text { Assesment for increasing student } \\
\text { achievement }\end{array}$ & $3.18(0.47)$ \\
\hline 36. & Coursework to support understanding & $3.64(0.52)$ \\
\hline 37. & Assesment process is more stable & $3.28(0.49)$ \\
\hline 38. & A learning outcome is measurable & $3.18(0.60)$ \\
\hline
\end{tabular}

\subsection{Subject Management}

The managing of economic subjects among teachers gives a more positive impact after the structural changes in the Form Six education system. Planning and managing economic subjects are efficient. The management of the students is efficient after reforms. However, the freedom to choose the subjects among themselves is limited. The facilities and equipment to help T\&L can still be improved. However, overall subject management received a positive impact as a result of changes in the system of learning from the terminal system to the modular system.

Table 5. Subject Management

\begin{tabular}{cll}
\hline No. & \multicolumn{1}{c}{ Subject management } & Mean (SD) \\
\hline 39. & Planning and learning are efficient & $3.05(0.40)$ \\
\hline 40. & Subject management is organised & $3.05(0.44)$ \\
\hline 41. & Monitoring implementation & $2.96(0.46)$ \\
\hline 43. & Management cooperation & $2.93(0.65)$ \\
\hline 44. & $\begin{array}{l}\text { Student information management is } \\
\text { more efficient }\end{array}$ & $3.02(0.41)$ \\
\hline 45. & $\begin{array}{l}\text { Improvement of facilities and } \\
\text { equipment }\end{array}$ & $2.75(0.54)$ \\
\hline 42. & Freedom in subjects selection & $2.95(0.55)$ \\
\hline 43. & Better Subject packages offered & $2.93(0.65)$ \\
\hline 44. & Students feel freedom & $2.91(0.54)$ \\
\hline
\end{tabular}

\subsection{Responsibility}

Any changes in the burden of duties as a result of changes in the pre-university education structure do not show a definite shift. However, Table 6 shows some items such as 'checking out exercises, holding an additional class to finish the measure' are two tasks that teachers need to take. Almost half of the teachers feel that time constraints have caused some of the functions of motivation and guidance to be implemented due to time constraints. Also, coursework is not obstacles for teachers to focus on teaching and learning. Co-curriculum-related burdens are not a burden that affects the preparation and implementation of the teaching and learning process.

Table 6. Responsibility

\begin{tabular}{|c|c|c|}
\hline No. & Responsibility/Workload & Mean (SD) \\
\hline 45. & Reviewing the student's task takes time & $2.81(0.55)$ \\
\hline 46. & $\begin{array}{l}\text { Regularly hold additional classes to } \\
\text { complete the curriculum }\end{array}$ & $2.96(0.69)$ \\
\hline 47. & $\begin{array}{l}\text { Enough time to analyse the results of the } \\
\text { exam }\end{array}$ & $2.96(0.67)$ \\
\hline 48. & $\begin{array}{l}\text { Motivation and guidance cannot be carried } \\
\text { out due to time constraint }\end{array}$ & $2.47(0.60)$ \\
\hline 49 & $\begin{array}{l}\text { The implementation of teaching is very } \\
\text { challenging }\end{array}$ & $3.09(0.49)$ \\
\hline 50. & More teaching and learning task load & $2.89(0.52)$ \\
\hline 51. & $\begin{array}{l}\text { Topic added and repaired are relevant to } \\
\text { the needs }\end{array}$ & $3.14(0.48)$ \\
\hline 52. & $\begin{array}{l}\text { Implementation of Course Work causes lost } \\
\text { focus in teaching }\end{array}$ & $2.40(0.62)$ \\
\hline 53. & $\begin{array}{l}\text { The duties of the co-curriculum advisor } \\
\text { teacher affect teaching's preparation }\end{array}$ & $2.16(0.49)$ \\
\hline 54. & $\begin{array}{l}\text { More time and energy for Co-curriculum } \\
\text { activity }\end{array}$ & $2.09(0.47)$ \\
\hline
\end{tabular}

\subsection{Demand and Supply}


The subject offer depends on the ability of the school regarding teaching staff and available facilities. On the other hand, the demand for this subject among students depends on the choice of the student itself apart from other factors. Teachers' responses indicate that more than $70 \%$ of teachers say that the numbers of students in the economic classes are declining. Almost four quarters of the respondents said that the subject offering packages did not help subject selection among the students. An equal number of respondents of the opinion that teachers are less likely to promote this subject.

Meanwhile, $43 \%$ of respondents felt that schools did not help in the process of encouraging students to continue their studies in Form Six education. Meanwhile, more than $90 \%$ of teachers think that better aid can help increase the demand for Form Six. Table 7 shows the items that are related to supply and demand.

Table 7. Demand and Supply

\begin{tabular}{lll}
\hline No & \multicolumn{1}{c}{ Demand and Supply } & Mean(SD) \\
\hline 55. & Economics students are increasing & $2.29(0.62)$ \\
\hline 56. & Subject packages help students & $2.84(0.64)$ \\
\hline 57. & $\begin{array}{l}\text { Economics teachers are promoting the } \\
\text { subject }\end{array}$ & $2.97(0.70)$ \\
\hline 58. & $\begin{array}{l}\text { Schools encourage Form Five students to } \\
\text { apply for Form Six. }\end{array}$ & $2.67(0.66)$ \\
\hline 59. & $\begin{array}{l}\text { Modular systems give more opportunities } \\
\text { to further studies }\end{array}$ & $3.24(0.50)$ \\
\hline 60. & $\begin{array}{l}\text { Number of classes that offered this subject } \\
\text { to increase }\end{array}$ & $3.24(0.51)$ \\
\hline 61. & Additional schooling support & $2.40(0.68)$ \\
\hline 62. & $\begin{array}{l}\text { Entry requirements of Form Six education } \\
\text { is quite stringent }\end{array}$ & $2.72(0.81)$ \\
\hline 63. & $\begin{array}{l}\text { Science Students can enter the Social } \\
\text { Science stream }\end{array}$ & $3.45(0.50)$ \\
\hline 64. & The school helps students choose packages & $3.12(0.68)$ \\
\hline 65. & $\begin{array}{l}\text { Students through a brief interview session } \\
\text { in the selection of the subject }\end{array}$ & $2.78(0.65)$ \\
\hline
\end{tabular}

\subsection{Overall Impact on Teaching and Learning}

Overall, the effect of changing the terminal learning system to the modular system is shown in Table 8. Overall, pre-university education shows that the modular system has a positive impact (six elements). The highest result is in the evaluation element, followed by the implementation of teaching and facilitating, and subject management. These three elements represent the mean values that have exceeded or are relative to three levels.

Table 8. Teaching and Learning Elements [Table 8]

\begin{tabular}{clccc}
\hline No & & Mean & SD & Affect \\
\hline 1. & $\begin{array}{l}\text { Teacher Planning and } \\
\text { preparation }\end{array}$ & 2.78 & 0.27 & Positive \\
\hline 2 & Student Preparation & 2.90 & 0.36 & Positive \\
\hline 3 & Implementation & 3.07 & 0.33 & Positive \\
\hline 4 & Assessment & 3.22 & 0.36 & Positive \\
\hline 5 & Subject Management & 2.92 & 0.34 & Positive \\
\hline 6 & Workload & 2.68 & 0.30 & Positive \\
\hline 7 & Demand and Supply & 2.87 & 0.33 & Positive \\
\hline & Total & 2.92 & 0.33 & Positive \\
\hline
\end{tabular}

\subsection{Student Achievement}

Student achievement for both the modular systems and terminal systems takes into account student achievements for both systems over four years. It means that the average performance of the terminal system and the four-year achievement of the modular system student are compared using the paired T-tests. The findings are shown in Table 9(a).

Table 9(a) shows the average achievement of four years for both systems. The performance of the terminal system is 2.6575 (the mean grade for the economic subject), and the modular system is 2.4532. The difference in achievement is 0.20426 , as shown in Table 9(c). The P-sample Analysis of Pairing showed a value of $\mathrm{t}(39, \mathrm{p}=$ $0.010)=2.704$, where the p-value is less than 0.05 . Therefore, the paired sample t-test shows that there is a significant difference in performance between the achievement of modular systems and terminal systems.

Table 9(a). Statistics

\begin{tabular}{cccccc}
\hline & Mean & $\mathrm{N}$ & $\begin{array}{c}\text { Standard } \\
\text { Deviation }\end{array}$ & Standard error \\
\hline Pair 1 & Modular & 2.6575 & 40 & .42632 & .06741 \\
\cline { 2 - 6 } & Terminal & 2.4532 & 40 & .40462 & .06398 \\
\hline \multicolumn{4}{c}{ Table 9(b). } & Independent Sample \\
\hline \multicolumn{4}{c}{ N } & Correlation & Significant \\
\hline Pair 1 $\begin{array}{c}\text { Modular \& } \\
\text { Terminal }\end{array}$ & 40 & .340 & .032 \\
\hline
\end{tabular}

Table 9(c). Paired sample test

\begin{tabular}{|c|c|c|c|c|c|c|c|c|c|}
\hline & & \multicolumn{5}{|c|}{ mean different } & \multirow{3}{*}{$\mathrm{T}$} & \multirow{3}{*}{ df } & \multirow{3}{*}{ Sig. (2 tails) } \\
\hline & & \multirow{2}{*}{ Mean } & \multirow{2}{*}{ SD } & \multirow{2}{*}{ SE } & \multicolumn{2}{|c|}{$95 \%$ Confident Interval } & & & \\
\hline & & & & & Lower & Upper & & & \\
\hline Pair 1 & Modular - Terminal & .20426 & .47766 & .07553 & .05149 & .35702 & 2.704 & 39 & .010 \\
\hline
\end{tabular}


The change in the F6 system from modular to terminal breath new changes to pre-university education generally. The extent to which these changes are beneficial or have a positive impact on teachers and students is the motivation for this study. The primary focus of the research is to examine the effect of this system or structure change on seven elements: teacher planning and preparation, student preparation, implementation of T\&L, evaluation system or assessment, subject management, task-free and final supply and demand.

The findings of the study found that all seven elements had a positive effect on the change. Implementation of T\&L has a significant impact on teachers and students. Changes from the terminal system to the modular or term system given opportunity for teachers to evaluate academic abilities in the first term/semester when they sit for the exam. The findings from interviews with teachers and focus groups emphasise that "students can evaluate their ability after sitting for the one-semester exam" \#1, \#3, $\# 4$, and \#5. They can also decide to remain in the F6education, if they are able, or seek an alternative by following other skills training", \#2, \#4, \#5, and \#6".

Contrary to the previous system, where students follow the terminal system with the final exam in the second year of the Sixth Form, but the modular system allows the student to complete the measure (microeconomics) in the first semester. Then, sit for the exam at the end of the semester. In semester two, students will study macroeconomics and will sit for the examination at the end of the semester. At the same time, students will receive the first term of the exam. Students are allowed to re-sit the exams for microeconomics paper if they are dissatisfied with the first term results at the end of the second term. This exam system will enable students to collect only the best results for university applications. According to the focus group, the system also took the students by surprise to have higher school examinations for selected subjects in the first semester. Students are previously waiting until the second year (in Malaysian Certificate of Education) before sitting for public exams, and this will indirectly create a new challenge before adapting to the terminal system.

In the context of preparation, planning and management of subjects for Form Six economic teachers, this change has a positive impact. Teachers are more likely to make plans because of the content of the economic subject is divided into three divisions, namely Microeconomics for the first term, Macro Economics for the second term and the third term the Malaysian Economy and Course Work. Generally, the effect is positive because teachers and students are more focused on the subject matter according to the measure. However, in the third term students had to prepare a challenging research paper for a $\mathrm{T} 6$ student. Teachers need to provide specific guidance so that student research papers meet the requirements of the scoring scheme. The majority of teachers think that excellent course results will help students to get good grades. If 'the result of quality coursework or meets the requirements of the scoring, then the students get a good result, \#1, \#2, \#3, \#4 and \#5". "I will make sure my students get the highest score for the coursework," \#5, "I believe the coursework gives students the advantage, \#5. Therefore, the preparation and planning of the teachers become more thorough, efficient and try to perform the best possible tasks to assist their students.

The opinion of teachers on student's planning, preparation and motivation vary. For those who choose to be in the F6 compared to pursuing a course of skill, or pursuing diploma level studies, they are more focused on their choice of the university through this channel. They convinced that they could get good results. According to the focus group, 'for those who choose or simply want to be in F6 because they have no choice, they are less motivated, less planned and eventually after only one semester will choose to quit when the results do not burst'.

The demand and supply of the economic subjects did not show any significant change. Indeed, the number of student selected this subject decreases over time. The modular system introduced so far is less effective in increasing student demand for this subject. Other options, such as Business Management and other subjects, are more attractive to students because of the difficulty of the economics subject, relatively. Our findings also show that there is a significant difference in the achievement between the modular group and the group of student terminals. This finding should be interpreted with caution because of several things. First, student groups vary according to the results year. Second, marks or achievements are taken for only four years, either terminal or modular because the implementation of the modular system is in the fourth year. The possibility of this factor or other factors can also affect these differences. However, the majority of teachers think that better student achievement in the modular system is due to the three main factors, the division of the term system allows students to focus more, re-sit exams and coursework component in the assessment.

\section{Conclusions}

Our findings suggest that the change in the system has a positive impact on teachers and students. Overall, student achievement has improved. They have the opportunity to improve their result by re-taking the exam. Some students tested their capabilities in the academic field in the first term, and they decided whether to stay in the academic line or choose another path of study. For teachers, the subject's management has improved, and their preparation for teaching and learning has a positive effect. In terms of demand, teachers and schools need to play an important role in attracting students to study at F6 education. The 
separation of school management from the mainstream should be considered as a priority seriously. The school management should be separated between upper secondary with the lower secondary education using the F6 college concept.

This study examines the changes in the pre-university education system or F6, which began in 2013. The policy changes from the terminal system to the modular system involved the curriculum, the implementation of teaching and learning based on the system and the shift in an assessment that included the concept of study through coursework. The findings show that this change has a positive impact on the six elements of teaching and learning process where evaluation (assessment), implementation and management of the subjects are the three main elements that have received the most critical effect. However, other components also have a positive impact.

\section{Limitation and Study Forward}

This study investigated the impact of pre-university education reforms. A significant changed was the duration of the study from two years to the three semesters. Consequently, the final assessment is at the end of each semester as compared to the previous system which is at the end of year two. Overall, our study found a positive impact of the education reforms for the teachers and students. However, the results from a small sample size should be generalised for the entire high schools. Furthermore, our findings based on the economic subject, which is considered as the toughest subject in arts category. Therefore, we are looking for a comprehensive study which is cover a bigger sample size and includes more subject at pre-university education. It is also important to compare the performance between college and high school administration.

\section{Acknowledgements}

The authors wish to express their gratitude and appreciation to the Universiti Pendidikan Sultan Idris for the research grant (Code: 2016-0104-107-01) that helped fund this research.

\section{REFERENCES}

[1] Bartlett, R. L. (2006). The evolution of cooperative learning and economics instruction. Teaching economics: More alternatives to chalk and talk, 39-58.

[2] Becker, W. E. (1997). Teaching economics to undergraduates. Journal of Economic Literature, 35(9),
1347-1373.

[3] Becker, W. E., \& Watts, M. (2001). Teaching economics at the start of the $21^{\text {st }}$ century: Still, chalk and talk. American Economic Review, 91 (May), 446-451.

[4] Becker, W. E., Becker, S. R., \& Watts, M. W. (Eds.). (2006). Teaching economics: More alternatives to chalk and talk. Edward Elgar Publishing.

[5] Berkhout, E., Berkhout, P., \& Webbink, D. (2011). The effects of a Dutch high school curriculum reform on performance in and after higher education. De Economist, 159(1), 41-61.

[6] Brokaw, A. J., \& Merz, T.E. (2004). Active Learning with Monty Hall in a Game Theory Class Journal of Economic Education, 35(3), 259-268.

[7] Buckles, S., \& Siegfried, J. J. (2006). Using multiple-choice questions to evaluate in-depth learning of economics. The Journal of Economic Education, 37(1), 48-57.

[8] Carlson, J. L., \& Skaggs, N.T. (2000). Learning by trial and error: A case for moot courts. Journal of Economic Education, 31(2), 145-155.

[9] Carlson, J. A., \& Velenchik, A. D. (2006). Using the case method in the economics classroom. WE Becker, SR Becker and MW Watts, Teaching Economics: More Alternatives to Chalk and Talk. Cheltenham, UK: Edward Elgar, 59-74. [done]

[10] Cross, P. K. (1987). Teaching for learning. AAHE Bulletin, 39(April), 2-7.

[11] Dixit, A. (2006). Evaluating recipes for development success. The World Bank. [done]

[12] Ginsburg, M. (2009). Active-learning pedagogies as a reform initiative: Synthesis of case studies. Washington, DC: Academy for Educational Development. Accessed on April, 7, 2010.

[13] Hansen, W. L. (2001). Expected proficiencies for undergraduate economics majors. Journal of Economic Education, 32 (Summer), 231-242.

[14] Jensen, E. J., \& Owen, A. L. (2003). Appealing to good students in introductory economics. Journal of Economic Education, 34(4), 299-325.

[15] Mnistry of Education (MOE) (2008). Amalan Terbaik Pembelajaran Aktif Dalam Ekonomi Asas (The best practise of active learning in Economics subject). Kuala Lumpur: Pusat Perkembangan Kurikulum.

[16] Khoo Yin Yin (2008). Keberkesanan Kaedah Penyelesaian Masalah Secara Kolaboratif Dalam Kalangan Pelajar Ekonomi Tingkatan Enam (The effectiveness of problem based solving with colaborative among Form Six students) . Unpulished PhD Thesis. Pulau Pinang: Universiti Sains Malaysia.

[17] Maier, M. H., \& Keenan, D. (1994). Cooperative learning in economics. Economic Inquiry, 32 (April), 358-361.

[18] Mahdzan, Ahmad. (2005). Kaedah Penyelidikan Sosio-Ekonomi. Kuala Lumpur: Dewan Bahasa dan Pustaka. [done] 
[19] Manning, L. A., \& Riordan, C.A. (2000). Using groupware software to support collaborative learning in economics. Journal of Economic Education, 31(3), 244-252.

[20] Meyers, C., \& Jones, T. B. (1993). Promoting Active Learning. Strategies for the College Classroom. Jossey-Bass Inc., Publishers, 350 Sansome Street, San Francisco, CA 94104. [done]

[21] Niemi, H. (1997). Active learning by teachers. In Active learning for students and teachers: Reports from eight countries (pp. 174-182). Lang. [done]

[22] Salemi, M. K. (2002). An Illustrated Case for Active Learning. Southern Economic Journal, 68(3), 721-731.

[23] Siegfried, J.J., Bartlett, R., Hansen, W.L., Kelley, A.C., McClosky, D.N., \& Tietenberg, T.H. (1991). The status and prospects of the economics major. Journal of Economic Education, 22(3), 195-224.

[24] Simons, P. R. J. (1997). Definitions and theories of active learning. Active learning for students and teachers, 19. [done]

[25] Slavin, R. E. (1990). Research on cooperative learning: Consensus and controversy. Educational Leadership, 47(4), 52-54.

[26] Strow, B. K., \& Strow, C. W. (2006). A rent-seeking experiment for the classroom. The Journal of Economic Education, 37(3), 323-330. [done]

[27] Whiting, C. (2006). Data-based Active Learning in the Principles of Macroeconomics course: A Mock FOMC Meeting. Journal Economics of Education, 37(2), 171-177.

[28] Yamaoka, M., Asano, T. \& Abe, S. (2010). The Present State of Economic Education in Japan. The Journal of Economic Education, 47(4), 448-460. 